\title{
HAEMOGLOBIN LEVEL AMONG THE REGULAR VOLUNTARY BLOOD DONORS
}

\author{
HOQUE MM ${ }^{1}$, ADNAN SD $^{2}$, BEGUM HA ${ }^{3}$, RAHMAN M ${ }^{4}$, RAHMAN SM ${ }^{5}$, MAMUN MAA ${ }^{6}$, FARUKI MA ${ }^{7}$
}

\begin{abstract}
:
Context: The need for blood is great and health of the blood donors is also the prime importance for the medical profession. The present study conducted to find out the pattern of haemoglobin level among the regular voluntary blood donor.
\end{abstract}

Methods: The present cross sectional study included 200 consecutive regular voluntary blood donors. The study conducted in the Department of Transfusion Medicine, Dhaka Medical College Hospital, Dhaka, between July 2010 and June 2011. The level of haemoglobin in donated blood was estimated by cyanmethaemoglobin method.

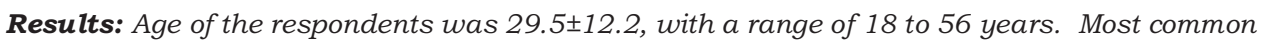
age group of respondents was 21 to 30 years and male and female ratio was 7.3:1. Among the male $90.3 \%$ had required haemoglobin level for blood donation and 9.7\% had haemoglobin level less than required. Among the female only $37.5 \%$ had required haemoglobin level for blood donation and $62.5 \%$ had haemoglobin level less than required. Out of 118 respondents aged less than 30 years, $89.8 \%$ had required haemoglobin level for blood donation and $10.2 \%$ had haemoglobin level less than required. Out of 82 respondents aged more than 30 years, $75.6 \%$ had required haemoglobin level for blood donation and $24.4 \%$ had haemoglobin level less than required.

Conclusion: The high frequency of decreased haemoglobin level among the regular voluntary blood donors found in this study suggests a need for a more accurate laboratory trial, since hemoglobin alone is not sufficient for detecting and excluding blood donors with iron deficiency without anemia.

Key words: Haemoglobin, Cross Sectional Study, Voluntary Blood Donors.

J Dhaka Med Coll. 2011; 20(2) : 168-173.

\section{Introduction:}

Blood transfusion is an essential component of health care which saves millions of lives each year. Donation of blood, the humanitarian act has been steadily declined while the demand for transfusion continues to rise ${ }^{1,2}$. Recruitment and retention of donors to sustain and increase the donor base are critical for blood banks ${ }^{3}$. Blood transfusion service is an integral and indispensable part of the healthcare system. The priority objective is to ensure safety, adequacy, accessibility and efficiency of blood supply at all levels ${ }^{4}$.

Anaemia is a condition characterized by a reduction in red cell mass and a decrease in the concentration of haemoglobin in the blood ${ }^{5}$. A large majority of the donor population in a developing country is deferred due to temporary

1. Dr Md. Mazharul Hoque, Assistant Professor, Department of Transfusion Medicine, Dhaka Medical College, Dhaka

2. Dr Sheikh Daud Adnan, Assistant Professor and Head, Department of Transfusion Medicine, Notional Institute of Cardiovascular Diseases, Dhaka.

3. Dr Hosne Ara Begum, Associate Professor, Department of Transfusion Medicine, Dhaka Medical College, Dhaka

4. Dr Mijanur Rahman, Assistant Professor, Department of Transfusion Medicine, Sir Salimullah Medical College, Dhaka

5. Dr Syeda Masooma Rahman, Assistant Professor, Department of Transfusion Medicine, Dhaka Medical College, Dhaka

6. Dr. Mohd. Abdullah Al Mamun, Project Officer, Anti-Tobacco Program, National Heart Foundation, Bangladesh, Mirpur, Dhaka

7. Dr Musanna Al Faruki, Honorary Medical Officer, Department of Medicine, Dhaka Medical College Hospital, Dhaka

Correspondence: Dr Md. Mazharul Hoque, Assistant Professor, Department of Transfusion Medicine, Dhaka Medical College, Dhaka. 
but easily correctable cause, anaemia ${ }^{5}$. Hemoglobin assessment is an important criterion for blood donor selection ${ }^{7}$. In Canada and the United States, the minimum values for donors haemoglobin concentration is set at $12.5 \mathrm{~g} / \mathrm{dl}$ for all blood donors ${ }^{8}$, while in European countries the cut-off level is $12.5 \mathrm{~g} / \mathrm{dl}$ for women and $13.5 \mathrm{~g} / \mathrm{dl}$ for men ${ }^{9}$. In 1999, FDA finalized the current rule establishing a minimum hemoglobin requirement of $12.5 \mathrm{~g} /$ $\mathrm{dL}$ or hematocrit of $38 \%$ for both male and female allogeneic donors. This rule also established an inter donation interval of eight weeks which is done to ensure both donor safety and appropriate hemoglobin content in the donated unit ${ }^{7-11}$. A recent report by Karp and King ${ }^{12}$ showed the variation in eligibility criteria for volunteer whole blood donors. Bangladesh Government has passed "Safe Blood Transfusion Law 2002" in the Parliament and in June'08 "Safe Blood Transfusion Rules 2008", was published ${ }^{4}$. In Bangladesh the minimum values of haemoglobin concentration for donors is set at $12.5 \mathrm{~g} / \mathrm{dl}$ for men and $11.5 \mathrm{~g} / \mathrm{dl}$ for women ${ }^{13}$.

Iron deficiency is the commonest cause of anemia worldwide ${ }^{6,14}$. Iron has a central role in erythropoiesis and is also involved in many other intracellular processes in all the tissues of the body ${ }^{15}$. A study from the United States suggested that up to $8.0 \%$ and $23.0 \%$ of male and female donors respectively may be iron deficient ${ }^{14}$. A healthy blood donor loses about 200-250 mg of iron per unit of blood donated ${ }^{7}$, 14. The body compensates for this loss by mobilizing iron stores in the form of ferritin ${ }^{14-}$ 16. If the lost iron stores in these donors are not replenished and they continue to donate blood, it results in iron deficiency anaemia and deferral of these donors in the future and a considerable number of regular donors who at present are the best source of safe blood will be lost ${ }^{16-18}$. In fact, iron deficiency anaemia is the main limiting factor in regular donors ${ }^{18-19}$. To the best of our knowledge no systematic study has been conducted in Bangladesh to assess the pattern of haemoglobin level in regular voluntary blood donors. The present study was conducted to find out the pattern of haemoglobin level among the regular voluntary blood donors in our population.

\section{Methods:}

The study was conducted in the Department of Transfusion Medicine, Dhaka Medical College Hospital, Dhaka, between July 2010 and June 2011. Total 200 consecutive regular voluntary blood donors were included in the study. Relevant history, clinical examination and sociodemographic data were collected from every respondent. The level of haemoglobin in donated blood was estimated by cyanmethaemoglobin method. Cut-off value of haemoglobin of $12.5 \mathrm{~g} / \mathrm{dl}$ for male and $11.5 \mathrm{~g} /$ $\mathrm{dl}$ for female is used as described by Bangladesh Gazette, $(2008)^{13}$. All data were analyzed by standard statistical software version 16.0 (SPSS, Chicago, IL, USA). The chi-square test was used for analysis of categorical data. A p value $<0.05$ was considered significant.

\section{Results:}

The mean age of the respondents was $29.5 \pm 12.2$ years, with a range of 18 to 56 years. Most common age group of respondents was 21 to 30 years followed by 31 to 40 years. Among the respondents 176 (88\%) were male and $24(12 \%)$ were female. Male to female ration was 7.3:1. In education highest number were in the level of higher secondary followed by graduate and above. In occupation 98 (49\%) were student, $46(23 \%)$ were service holder, $23(11.5 \%)$ were businessman and rest 33 (16.5\%) were unemployed. ABO blood grouping of 96 (48.0\%) was 'O', 48 (24\%) was 'B', 40 (20\%) was 'A' and rest $16(8 \%)$ was 'AB' blood group. $\mathrm{Rh}$ positive and $\mathrm{Rh}$ negative were 184 (92\%) and $16(8 \%)$ respectively. Among the male, 159 (90.3\%) had haemoglobin level e"12.5 gm/dl and 17 (9.7\%) had haemoglobin level $<12.5 \mathrm{gm} /$ dl and among the female $9(37.5 \%)$ had haemoglobin level $>11.5 \mathrm{gm} / \mathrm{dl}$ and $15(62.5 \%)$ had haemoglobin level $<11.5 \mathrm{gm} / \mathrm{dl}$. Out of 118 respondents aged less than 30 years, 106 $(89.8 \%)$ had required haemoglobin level for blood donation and $12(10.2 \%)$ had haemoglobin level less than required. Out of 82 respondents aged more than 30 years, 62 (75.6\%) had required haemoglobin level for blood donation and $20(24.4 \%)$ had haemoglobin level less than required. 
Table-I

Distribution of characteristics of the respondents

\begin{tabular}{lcc}
\hline Variable & Frequency & Percentage \\
\hline Age group & 23 & \\
$<20$ & 95 & 41.5 \\
$21-30$ & 65 & 32.5 \\
$31-40$ & 12 & 06.0 \\
$41-50$ & 05 & 02.5 \\
$>50$ & $29.5 \pm 12.2(18-56)$ \\
Mean \pm SD (Range) & & \\
Sex & 176 & 88.0 \\
Male & 24 & 12.0 \\
Female & \\
Male Female ratio & $7.3: 1$ & \\
Educational status & & \\
No education & 08 & 04.0 \\
Primary & 12 & 06.0 \\
Secondary & 36 & 18.0 \\
Higher secondary & 92 & 46.0 \\
Graduate and above & 52 & 26.0 \\
Occupation & & \\
Student & 98 & 49.0 \\
Service & 46 & 23.0 \\
Business & 23 & 11.5 \\
Unemployed & 33 & 16.5 \\
\hline
\end{tabular}

Table -II

Distribution of $A B O$ blood grouping and Rh typing

\begin{tabular}{lccc}
\hline ABO & \multicolumn{2}{c}{ Rh typing } & Total \\
grouping & Rh positive & Rh & negative \\
\hline O & 92 & 04 & $96(48.0)$ \\
$\mathrm{B}$ & 41 & 07 & $48(24.0)$ \\
$\mathrm{A}$ & 36 & 04 & $40(20.0)$ \\
$\mathrm{AB}$ & 15 & 01 & $16(08.0)$ \\
\hline Total & 184 & 16 & $200(100.0)$ \\
\hline
\end{tabular}

Table -III

Distribution of haemoglobin level according to cutoff value required for blood donation of the respondents

\begin{tabular}{lcc}
\hline Haemoglobin level & Frequency & Percentage \\
\hline$>12.5 \mathrm{gm} / \mathrm{dl}$ for male \& & 168 & 84.0 \\
$>11.5 \mathrm{gm} / \mathrm{d}$ l for female & & \\
$<12.5 \mathrm{gm} / \mathrm{d} 1$ for male $\&$ & 032 & 16.0 \\
$<11.5 \mathrm{gm} / \mathrm{d} 1$ for female & & \\
\hline Total & 200 & 100.0 \\
\hline
\end{tabular}

Table -IV

Relationship of haemoglobin level with sex

\begin{tabular}{|c|c|c|}
\hline \multirow[t]{2}{*}{ Haemoglobin level } & \multicolumn{2}{|c|}{ Sex } \\
\hline & Male & $\begin{array}{l}\text { P value* } \\
\text { e }\end{array}$ \\
\hline \multicolumn{3}{|l|}{$>12.5 \mathrm{gm} / \mathrm{dl}$ for male $\&$} \\
\hline > $11.5 \mathrm{gm} / \mathrm{dl}$ for female & $159(90.3)^{\#}$ & 09(37.5) 0.000 \\
\hline \multicolumn{3}{|l|}{$<12.5 \mathrm{gm} / \mathrm{dl}$ for male $\&$} \\
\hline$<11.5 \mathrm{gm} / \mathrm{dl}$ for female & $017(09.7)$ & $15(62.5)$ \\
\hline Total & 176(100.0) & $24(100.0)$ \\
\hline
\end{tabular}

*Chi-square test was done to measure the level of significance.

\#Figure within parentheses indicates in column percentage.

Table-V

Relationship of haemoglobin level with age

\begin{tabular}{|c|c|c|c|}
\hline \multirow[t]{2}{*}{ Haemoglobin level } & \multicolumn{2}{|c|}{ Age group } & \multirow{2}{*}{$\begin{array}{c}\mathrm{P} \\
\text { value }\end{array}$} \\
\hline & $<30$ & $>30$ & \\
\hline \multicolumn{3}{|l|}{$\begin{array}{l}\text { ed } 12.5 \mathrm{gm} / \mathrm{dl} \text { for male } \& \\
\text { ed } 11.5 \mathrm{gm} / \mathrm{dl} \text { for female }\end{array}$} & \multirow[t]{2}{*}{0.007} \\
\hline $\begin{array}{l}<12.5 \mathrm{gm} / \mathrm{dl} \text { for male } \& \\
<11.5 \mathrm{gm} / \mathrm{dl} \text { for female }\end{array}$ & $012(10.2)$ & $20(24.4)$ & \\
\hline otal & $118(100.0)$ & $82(100.0)$ & \\
\hline
\end{tabular}

${ }^{*}$ Chi-square test was done to measure the level of significance.

\#Figure within parentheses indicates in column percentage.

\section{Discussion:}

The present cross sectional study was conducted to find out the pattern of haemoglobin among the regular voluntary blood donors. In the present study the most common age group of respondents was 21 to 30 years followed by 31 to 40 years and the mean age of the respondents was $29.5 \pm 12.2$ years. Agnihotri ${ }^{20}$ in a study showed that the majority $(57.7 \%)$ of the donors presenting for the donation were between 25 and 39 years of age. Olokoba et al. ${ }^{21}$ in a study found the age range of blood donors was 18 to 61 years with a mean of 31.3 years. This is similar to that in the study of Khan et al. ${ }^{22}$ and Muktar et al. ${ }^{23}$. However the study conducted by Egah et al. ${ }^{24}$ showed the age range 21 to 50 years. Kimani et al. ${ }^{25}$ 
in a study showed that the majority of voluntary donors were less than 25 years old. Ray et al. ${ }^{1}$ in their study showed that $48 \%$ donors belonged to the age group 16-25 years with a range of 19 to 53 years. Studies by Sullivan et al. ${ }^{26}$ and Kandle et al. ${ }^{27}$ showed that the most of the voluntary blood donors belong to the younger age group.

In the study $176(88.0 \%)$ were male and 24 $(12.0 \%)$ were female. Male to female ration was 7.3:1. Studies by Olokoba et al. ${ }^{21}$ and Egah et al. ${ }^{24}$ showed that male blood donors were $96.0 \%$ and $95.0 \%$ respectively. Muktar et al. ${ }^{23}$ found $98.0 \%$ of their donors were male while Nwokediuko et al. ${ }^{28}$ found that $91.8 \%$ donors were male. However, all the donors were male in the studies of Elfaki et al. ${ }^{29}$ and Khan et al. ${ }^{22}$. In a study Agnihotri ${ }^{20}$ showed that of the total donors who presented for blood donation $10 \%$ were female, however majority of them were deferred so that they contributed only $5.2 \%$ of selected donors. Ray et al. ${ }^{1}$ in a study of 300 voluntary donors showed that $89.3 \%$ were males and $10.7 \%$ females.

In education highest number was in the level of higher secondary followed by graduate and above. In occupation 98 (49.0\%) were student, $46(23 /-\%)$ were service holder, $23(11.5 \%)$ were businessman and rest $33(16.5 \%)$ were unemployed (Table 1). Gao et al. ${ }^{30}$ in a study reported that the occupation of blood donors was widely distributed.

Among the male donors 90.3\% had haemoglobin level e" $12.5 \mathrm{gm} / \mathrm{dl}$ and among the female only 37.5 had haemoglobin level e" 11.5 $\mathrm{gm} / \mathrm{dl}$ that required for blood donation according to Save Blood Transfusion Rules ${ }^{13}$. There is statistically significant difference observed in haemoglobin level between male and female donor $(p<0.05)$. Rushton et $a .^{31}$ found that of all the primates, only in humans do females have lower blood haemoglobin concentrations than males. Mahida et al. ${ }^{32}$ in a study showed that, $9.5 \%$ male and $26.7 \%$ female regular voluntary blood donors developed anaemia, defined as $\mathrm{Hb}$ below $12.5 \mathrm{~g} / \mathrm{dl}$. Sunder and Vivekanand ${ }^{33}$ conducted a study in Bangalore, South India and reported the incidence of anaemia as $2.4 \%$ in male and $19.7 \%$ in female donors. All the female participants of the present study were in pre-menopausal age group; hence, they may have developed anaemia. Significant correlation between the number of donations and hemoglobin level $\left(\mathrm{r}^{2}\right.$ $=0.061$ ) was noted in a study by Norashikin et al. ${ }^{14}$. Alvarez-Ossorio et al. ${ }^{19}$ reported that 30\% and $26 \%$ of women regular blood donors had respectively iron deficiency and iron deficiency anaemia. Among the respondents aged less than 30 years, $89.8 \%$ had haemoglobin level required for blood donation and $10.2 \%$ had less haemoglobin level than required. In the present it was found that haemoglobin level less than required for blood donation more prevalent among the donor aged more than 30 years. Among the respondents aged more than 30 years, $75.6 \%$ had haemoglobin level required for blood donation and $24.4 \%$ had haemoglobin level less than required for blood donation. There is statistically significant difference observed in haemoglobin level between age group more and less than 30 years $(\mathrm{p}<0.05)$.

Blood centers should establish expanded donor health screening programs in improving donor health, donor recruitment, and donor retention ${ }^{34}$. Taken together, a declining donation rate and an increase in the consumption of blood components require novel approaches on both sides of the blood supply chain $^{35}$.

\section{Conclusion:}

The high frequency of decreased haemoglobin level among the regular voluntary blood donors suggests a need for a more accurate laboratory trial. Predicted haemoglobin levels for blood donation may be normal in the presence of reduced iron stores, individuals potentially at risk for developing iron deficiency anaemia can be detected only by serum ferritin estimation. Therefore iron status of the donors needs to be identified and necessary steps for iron supplementation need to be taken, which is especially relevant with the global and national drive to recruit and retain regular repeat voluntary blood donors. 


\section{References:}

1. Ray S, Singh Z, Banerjee A. Psychosocial Variables of Voluntary Blood Donors at Blood Bank of a Medical College. MJAFI 2005; 61: 130-2.

2. Watanabe KK, Screiber GB, Hayes A, Williams AE. Factors influencing the recruitment and retention of young donors. Transfusion 1999; 39 Suppl: 320.

3. WHO report on World Health Day 2000. Strategies for safe blood transfusion. Available at: www. who. int [Accessed on 12 March, 2011].

4. Islam MB. Blood transfusion services in Bangladesh. Asian J Transfus Sci 2009; 3(2): 10810 .

5. Ahmed F. Anaemia in Bangladesh: a review of prevalence and aetiology. Public Health Nutr 2000; 3(4): 385-93.

6. Bahadur S, Pujani M, Jain M. Donor deferral due to anemia: A tertiary care center-based study. Asian J Transfus Sci 2011; 5: 53-5.

7. Temper BJ. Minerals, the central nervous system and behaviour. In: Worobey J, Temper BJ, Kanarek RB. eds. Nutrition and behaviour: a multidisciplinary approach. Cambridge: CABI Publishing; 2006; p. 100.

8. Goldman MR. Another stab at donor haemoglobin screening. Transfusion 2005; 45: 1552-3.

9. Council of Europe. Guide to the preparation, use and quality assurance of blood components. $9^{\text {th }}$ ed. Strasbourg: Council of Europe Publishing; 2003.

10. Newman B. Iron depletion by whole-blood donation harms menstruating females: the current whole-blood-collection paradigm needs to be changed. Transfusion 2006; 46(10): 1667-81.

11. Newman B. Improving the US blood supply and blood donation safety for both women and men. Transfusion 2008; 48(5): 1032-5.

12. Karp JK and King KE. International variation in volunteer whole blood donor eligibility criteria Transfusion 2010; 50: 507-13.

13. 'Save Blood Transfusion Rules' 2008. Bangladesh Gazette, June 2008.

14. Norashikin J, Roshan TM, Rosline H, Zaidah AW, Suhair AA, Rapiaah M. A study of serum ferritin levels among male blood donors in Hospital Universiti Sains Malaysia. Southeast Asian J Trop Med Public Health 2006; 37: 370-3.

15. Cancado RD, Chiattone CS, Alonso FF, Langhi Jr. DM, Alves RCS. Iron deficiency in blood donors. Sao Paulo Med J 2001; 119(4): 132-4.

16. Djalali M, Neyestani TR, Bateni J, Siassi F. The effect of repeated blood donations on the iron status of Iranian blood donors attending the Iranian blood transfusion organization. Int $\mathrm{J}$ Vitam Nutr Res 2006; 76(3): 132-7.

17. Simon TL. Iron, iron everywhere but not enough to date. Transfusion 2002; 42: 664-5.

18. Finch CA, Cook JD, Labble RF, Cuala M. Effect of blood donation on iron stores as evaluated by serum ferritin. Blood 1977; 50: 441-7.

19. Alvarez-Ossorio L, Kirchner H, Klüter H, Schlenke P. Low ferritin levels indicate the need for iron supplementation: strategy to minimize irondepletion in regular blood donors. Transfus Med 2000; 10(2): 107-12.

20. Agnihotri N. Whole blood donor deferral analysis at a center in Western India. Asian $\mathrm{J}$ Transfus Sci 2010; 4(2): 116-22.

21. Olokoba AB, Salawu FK, Danburam A, Desalu OO, Olokoba LB, Wahab KW, et al. Viral Hepatitides in Voluntary Blood Donors in Yola, Nigeria. European J Scient Res 2009; 31(3): 329-34.

22. Khan Z, Raziq F, Aslam N. Prevalence of HIV in N.W.F.P. J Postgrad Med Inst 2002; 16(2): 187-9.

23. Muktar HM, Suleiman AM, Jones M. Safety of blood transfusion: prevalence of hepatitis B surface antigen in blood donors in Zaria, Northern Nigeria. Nigerian J Surg Res 2005; 7(3\&4): 2902 .

24. Egah DZ, Mandong BM, Iya D, Gomwalk NE, Audu ES, Banwat EB. Hepatitis C virus antibodies among blood donors in Jos, Nigeria. Ann Afr Med 2004; $3(1): 35-7$.

25. Kimani D, Mwangi J, Mwangi M, Bunnell R, Kellogg TA, Oluoch T, et al. Blood donors in Kenya: a comparison of voluntary and family replacement donors based on a population-based survey. Vox Sanguinis 2011; 100(2): 212-8.

26. Sullivan MT, Umana WO, Williams AE, Bianco CE. Donationincentives provided by blood centers and blood drive sponsors in the US. Transfusion 2000; 40(4 Supp1): 35-6.

27. Kandle SK, Ghatole MP, Jahagirdar. Behavioural risk factors for acquisition of HIV infection in voluntary blood donors in Solapur. Indian Med Gazette 2001; 41-4.

28. Nwokediuko SC, Ibegbulam OG, Ugwu T. Hepatitis $\mathrm{C}$ virus seroprevalence in blood donors at the University of Nigeria Teaching Hospital, Enugu. J Coll Med 2007; 12(2): 85-8.

29. Elfaki AM, Eldour AA, Elsheikh NM. Seroprevalence of immunodeficiency virus, hepatitis $\mathrm{B}$ and $\mathrm{C}$ and syphilis among blood donors at ElObeid Teaching Hospital, West Sudan. Sudan J Med Sci 2008; 3(4): 333-8. 
30. Gao X, Cui Q, Xiang S, Su J, Peng Z, Chen X, et al. Prevalence and trend of hepatitis $C$ virus infection among blood donors in Chinese mainland: a systematic review and meta-analysis. BMC Infectious Diseases 2011; 11: 88.

31. Rushton DH, Dover R, Sainsbury AW, Norris MJ, Gilkes JJH, Ramsay ID. Why should women have lower reference limits for haemoglobin and ferritin concentrations than men? BMJ 2001; 322: 1355-7.

32. Mahida VI, Bhatti A, Gupte SC. Iron status of regular voluntary blood donors. Asian J Transfus Sci 2008; 2(1): 9-12.
33. Sunder P and Vivekanand J. Anemia among blood donors in Bangalore. Transfusion Bull 2002; 10: 9-11.

34. Reiss RF. Blood donor well-being: a primary responsibility of blood collection agencies. Ann Clin Lab Sci 2011; 41(1): 3-7.

35. Seifried E, Klueter H, Weidmann C, Staudenmaier $\mathrm{T}$, Schrezenmeier H, Henschler R, et al. How much blood is needed? Vox Sang. 2011; 100(1): 10-21. 